University of Wollongong

Research Online

Faculty of Engineering and Information

Faculty of Engineering and Information

Sciences - Papers: Part A

Sciences

$1-1-2013$

Effects of geosynthetic reinforcement on performance of ballasted rail track

Pongpipat Anantanasakul

University of Wollongong, pongpipa@uow.edu.au

Buddhima Indraratna

University of Wollongong, indra@uow.edu.au

Sanjay S. Nimbalkar

University of Wollongong, sanjayn@uow.edu.au

Tim Neville

Australian Rail Track Corporation Ltd

Follow this and additional works at: https://ro.uow.edu.au/eispapers

Part of the Engineering Commons, and the Science and Technology Studies Commons

Research Online is the open access institutional repository for the University of Wollongong. For further information contact the UOW Library: research-pubs@uow.edu.au 


\title{
Effects of geosynthetic reinforcement on performance of ballasted rail track
}

\begin{abstract}
The 'field' performance of different geosynthetics to reinforce ballasted rail tracks was investigated. An extensive monitoring program was undertaken on fully instrumented track sections constructed near Singleton, New South Wales. Four types of geosynthetics were installed at the ballast-subballast interface of track sections located on subgrades with three distinctly different values of stiffness. It was found that geogrids could decrease vertical settlements of the ballast layer with obvious benefits of improved track stability and decreased maintenance cost. It was also found that the effectiveness of reinforcing geogrids increased when the subgrade stiffness decreased. Keywords: Geosynthetic, Reinforcement, Rail track, Ballast.
\end{abstract}

Keywords

performance, ballasted, rail, track, effects, geosynthetic, reinforcement

Disciplines

Engineering | Science and Technology Studies

\section{Publication Details}

Anantanasakul, P., Indraratna, B., Nimbalkar, S. S. \& Neville, T. (2013). Effects of geosynthetic reinforcement on performance of ballasted rail track. In B. Indraratna, C. Rujikiatkamjorn \& J. S. Vinod (Eds.), Proceedings of the International Conference on Ground Improvement and Ground Control (pp. 937-944). Singapore: Research Publishing. 


\title{
EFFECTS OF GEOSYNTHETIC REINFORCEMENT ON PERFORMANCE OF BALLASTED RAIL TRACK
}

\author{
Pongpipat Anantanasakul ${ }^{1, a}$, Buddhima Indraratna ${ }^{2}$, Sanjay S. Nimbalkar ${ }^{1, b}$ \\ and Tim Neville ${ }^{3}$ \\ ${ }^{1}$ School of Civil, Mining and Environmental Engineering, \\ University of Wollongong, NSW 2522, Australia. \\ E-mail: ${ }^{a}$ pongpipa@uow.edu.au, ${ }^{b}$ sanjayn@uow.edu.au \\ ${ }^{2}$ School of Civil, Mining and Environmental Engineering, \\ University of Wollongong, NSW 2522, Australia. E-mail: indra@uow.edu.au \\ ${ }^{3}$ Geotechnical Engineer, Australian Rail Track Cooperation Ltd., Broadmeadow, \\ NSW 2292, Australia. E-mail: tneville@artc.com.au
}

\begin{abstract}
The 'field' performance of different geosynthetics to reinforce ballasted rail tracks was investigated. An extensive monitoring program was undertaken on fully instrumented track sections constructed near Singleton, New South Wales. Four types of geosynthetics were installed at the ballast-subballast interface of track sections located on subgrades with three distinctly different values of stiffness. It was found that geogrids could decrease vertical settlements of the ballast layer with obvious benefits of improved track stability and decreased maintenance cost. It was also found that the effectiveness of reinforcing geogrids increased when the subgrade stiffness decreased.
\end{abstract}

Keywords: Geosynthetic, Reinforcement, Rail track, Ballast.

\section{INTRODUCTION}

Ballasted rail tracks serve as one of the major infrastructure for freight and passenger transport in Australia. In recent years, an increasing demand for such transport has led to the use of considerably heavier and faster trains. Large cyclic stresses from train traffic can induce large deformations and degradation of the ballast layer (McDowell and Harireche 2002 and Lackenby et al., 2007). This, in turn, adversely affects track stability and increases frequency of track maintenance.

It has been observed from several laboratory studies (Rowe and Jones 2000, Shin et al., 2002, Brown et al., 2007 and Indraratna et al., 2011, among others) that layers of geosynthetics when placed in the track substructure can increase stability and therefore longevity of ballasted rail tracks. Nevertheless, only a few studies have investigated the benefits of geosynthetic reinforcement under 'field' conditions. Among these studies, Indraratna et al. (2010) performed a field study on a track, in which layers of geocomposite were installed at the ballast-subballast interface. They reported up to $40 \%$ smaller vertical and horizontal strains of the ballast layer for the reinforced track part.

Proceedings of the International Conference on Ground Improvement and Ground Control

Edited by Buddhima Indraratna, Cholachat Rujikiatkamjorn and Jayan S. Vinod

Copyright (C) 2012 by Research Publishing Services. All rights reserved.

ISBN: 978-981-07-1896-1 :: doi:10.3850/978-981-07-1896-1_03-0315 
However, the 'field' performance of different geosynthetics used as reinforcing elements for ballasted tracks has not been investigated in a systematic manner. The present study was undertaken to fill this gap. Nine experimental track sections were constructed near the city of Singleton, New South Wales. These fully instrumented track sections were built on three subgrades with distinctly different values of stiffness, and four types of geosynthetics were installed at the ballast-subballast interface. Permanent and transient strains of ballast, breakage of particles, and variation of vertical stresses in the track substructure were routinely monitored. This paper presents the details of experimental program as well as preliminary field monitoring results of this unique study.

\section{EXPERIMENTAL TRACK SECTIONS}

The experimental track sections were part of the Third Track of the Minimbah Bank Stage 1 Line that extended from Bedford (chainage $224.20 \mathrm{~km}$ ) to Singleton $(235.06 \mathrm{~km})$, New South Wales. A subsurface exploration program indicated that the Third Track was located on an extensive medium to high strength siltstone outcrop between 224.20 to $229.00 \mathrm{~km}$ and on the flood plain of the nearby Hunter River thereafter (RCA Australia 2008). The flood plain consisted of a layer of alluvial silty clay deposit 7-10 $\mathrm{m}$ thick underlain by heterogeneous layers of medium dense sand and silty clay with a total thickness of 7-9 $\mathrm{m}$. Medium strength siltstone was found beneath the sand-silty clay layer.

The Third Track's substructure consisted of a ballast layer (GP, compacted latite basalt fragments, $D_{50}=36 \mathrm{~mm}$ ) which extended about $300 \mathrm{~mm}$ below sleepers. It was underlain by a $150 \mathrm{~mm}$ thick subballast layer (GP-GM, compacted sandy gravel, CBR $=50 \%$, $D_{50}=4 \mathrm{~mm}$ ). A structural fill layer of $700 \mathrm{~mm}$ thickness (GP-GM, compacted sandy gravel, CBR $8 \%, D_{50}=3 \mathrm{~mm}$ ) was placed below the subballast layer. For the first track part, the structural fill was underlain by cut siltstone. For the first half of the second track part, the structural fill was underlain by a layer of general fill (clayey-silty gravels) and followed by the original alluvial silty clay. The structural fill was placed directly on the original alluvial silty clay deposit for the rest of track. The track crossed three natural waterways and reinforced concrete bridges were constructed to support the track at these locations.

Nine experimental sections were included in the Third Track at the time of track construction. Four types of geosynthetics were installed at the ballast-subballast interface to study their potential benefits at improving the overall track stability. The experimental sections were located on subgrades with three different values of stiffness. This was done to also study the effects of varying subgrade stiffness on the performance of geosynthetic reinforcement. The three subgrades were (i) the relatively soft general fill and alluvial silty clay deposit (Sections 1-5 and A), (ii) the intermediate siltstone (Sections 6 and C) and (iii) the stiff reinforced concrete bridge deck (Section B). Figure 1 shows the locations of experimental sections on different parts of the Third Track.

Figure 2 shows different types of geosynthetics installed at the experimental sections. Single layers of EnkaGrid, TensarGrid, and TerraGrid were installed in Sections 1-4. A single layer of CombiGrid (geocomposite) was installed at Section 5, while a layer of TerraGrid was installed at Section 6. For comparison purposes, no geosynthetic was installed at Sections A and C. A layer of ShockMat (synthetic mat) was installed at the ballast-deck interface at Section B (Figure 2b) to minimize particle degradation. Table 1 lists the values of mechanical properties of the geosynthetics employed. 


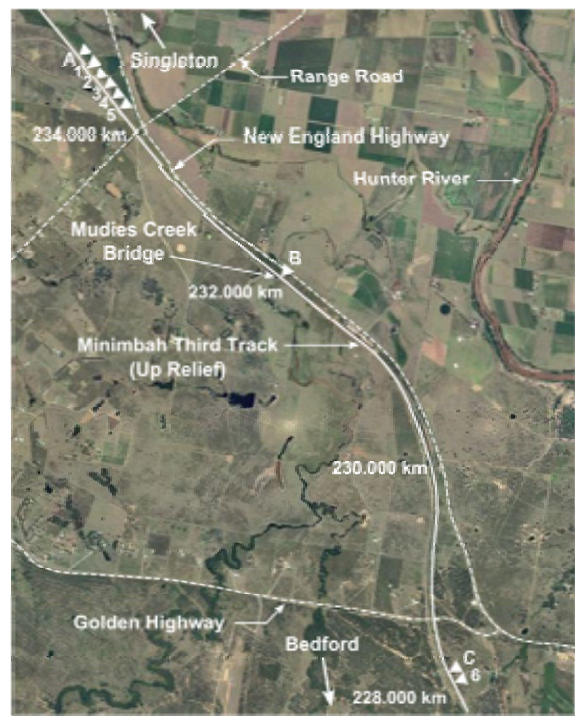

Figure 1. Locations of experimental sections on Minimbah Third Track.

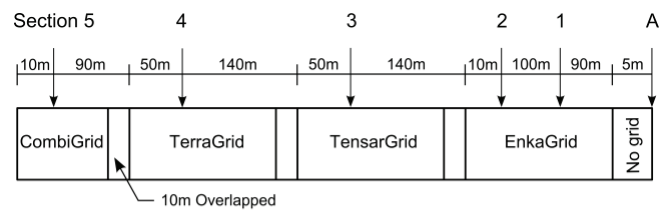

(a)

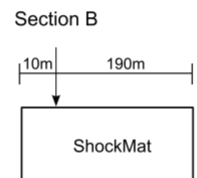

(b)

Section $6 \quad \mathrm{C}$

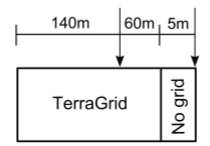

(c)

Figure 2. Reinforcement of track substructure with different geosynthetics.

Table 1. Properties of (a) geogrids and geocomposite and (b) synthetic mat. * indicates values in 'machine' followed by 'cross-machine' direction.

\begin{tabular}{|c|c|c|c|c|c|c|c|}
\hline \multirow[b]{2}{*}{ Material } & \multirow{2}{*}{$\begin{array}{l}\text { TerraGrid } \\
\text { polyester }\end{array}$} & \multirow{2}{*}{$\begin{array}{c}\text { TensarGrid } \\
\text { polyester }\end{array}$} & \multirow{2}{*}{$\begin{array}{l}\text { EnkaGrid } \\
\text { polyester } \\
\text { (grid) }\end{array}$} & \multicolumn{2}{|c|}{ CombiGrid } & \multicolumn{2}{|r|}{ ShockMat } \\
\hline & & & & $\begin{array}{l}\text { polypropelene } \\
\text { (fabric) }\end{array}$ & polypropelene & Material & $\begin{array}{c}\text { Polyurethane } \\
\text { elastomer }\end{array}$ \\
\hline Type & biaxial & biaxial & biaxial & biaxial & nonwoven & Type & bonded rubber \\
\hline Tensile strength* $(\mathrm{kN} / \mathrm{m})$ & $30 / 30$ & $30 / 30$ & $36 / 36$ & $40 / 40$ & $6 / 10$ & & granulates \\
\hline Strain at break $(\%)$ & $15 / 15$ & $15 / 15$ & $15 / 15$ & $15 / 15$ & $60 / 40$ & Particle size $(\mathrm{mm})$ & $1-3$ \\
\hline Aperture size $^{*}(\mathrm{~mm})$ & $40 / 40$ & $65 / 65$ & $44 / 44$ & $31 / 31$ & - & $\begin{array}{l}\text { Tensile strength }(\mathrm{kN} / \mathrm{m} 2) \\
\text { Strain at break }(\%)\end{array}$ & $\begin{array}{c}600 \\
80\end{array}$ \\
\hline Thickness (mm) & 4 & 3 & 3 & 3 & 2.9 & Thickness $(\mathrm{mm})$ & $\begin{array}{l}80 \\
10\end{array}$ \\
\hline
\end{tabular}

\section{TRACK INSTRUMENTATION}

Traffic induced vertical stresses in the track were monitored by pressure cells that were suitable to measure compressive stresses up to $600 \mathrm{kPa}$. Two pressure cells were installed at Sections 1, 6, A and C (Figure 3a). One pressure cell was installed at the sleeper-ballast and another at the ballast-subballast interface. At Section B, however, three pressure cells were installed at the synthetic mat-deck interface. Two cells were located below the up rail while the other was below the down rail. Strain gauges were used to study deformations and mobilized forces along the geogrid layers. The strain gauges were of post-yield type and suitable to measure strains in the range of 0.1 to $15 \%$. They were installed, in group, on the top and bottom sides of grids in both longitudinal and transverse directions as shown in Figure 3b.

Settlement pegs were installed to monitor vertical settlements of the ballast layer. The settlement pegs were installed at the sleeper-ballast and ballast-subballast interfaces (Figure 3c). A simple survey technique was used to track the movements of pegs and settlements of the ballast layer were later determined. Transient deformations of the ballast layer 


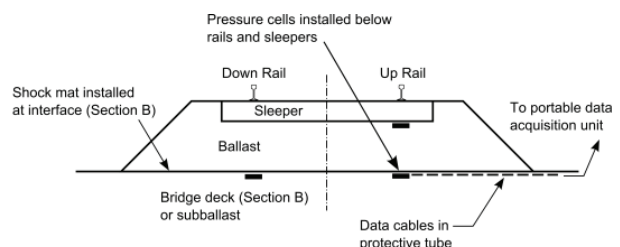

(a)

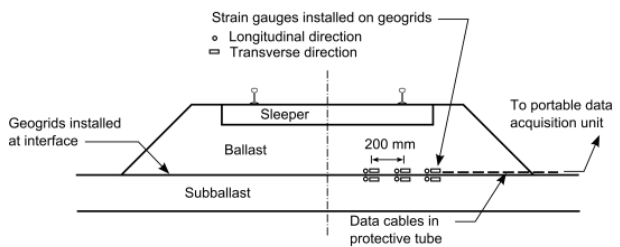

(b)



(c)

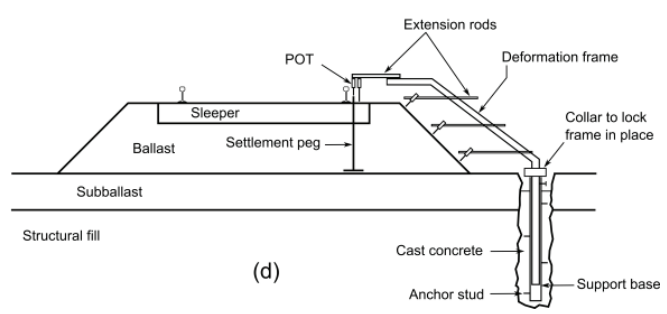

Figure 3. Details of track instrumentation using (a) pressure cells, (b) strain gauges, (c) settlement pegs and (d) potentiometers (POTs) mounted on deformation frame.

were measured by potentiometers (POTs) mounted on a custom aluminum frame as shown in Figure 3d. Two POTs, one monitoring the vertical movement of sleepers while another for that of the ballast-subballast pegs, determined transient vertical deformations of the ballast layer. The other three POTs mounted in an inclined fashion monitored both vertical and horizontal deformations of the ballast shoulder at different locations. The deformation frame was used at all experimental sections, except Section B. The frame was held in place by support bases installed in the subballast and structural fill layers.

Data from the pressure cells, strain gauges and POTs as well as levels of the settlement pegs were obtained immediately after the instruments were installed. Later on, data were obtained daily for three days, weekly for three weeks, monthly for three months and quarterly for three quarters.

\section{PRELIMINARY FIELD MONITORING RESULTS}

\subsection{Transient Vertical Stresses}

The vertical stresses $\left(\sigma_{v}\right)$ due to the passage of trains with an axle load of 30 tons and a speed of $40 \mathrm{~km} / \mathrm{hr}$ for Sections 1 and A were in the range of 170 to $180 \mathrm{kPa}$ and 30 to $35 \mathrm{kPa}$ at the sleeper-ballast and ballast-subballast interface, respectively. At Section B, the vertical stresses at the mat-deck interface were about $280 \mathrm{kPa}$. These results indicate that the induced stresses were considerably larger in a track with stiffer subgrade. The larger stresses also caused higher degrees of breakage of the individual ballast particles as expected. The value of ballast breakage index (BBI) at 310 days after track commission $\left(7.8 \times 10^{5}\right.$ load cycles) for Section B was $16 \%$ while that of Section A was $9.8 \%$.

\subsection{Settlements of Ballast Layer}

The settlements $\left(S_{v}\right)$ and vertical strains $\left(\varepsilon_{v}\right)$ of ballast layer at 90 days after track commission $\left(2.3 \times 10^{5}\right.$ load cycles) are reported in Table 2 . When the results for sections on similar subgrades are compared, the vertical settlements of sections with reinforcement are 10$32 \%$ smaller than those without reinforcement. This phenomenon is similarly observed in 
Table 2. Vertical settlements and strains of ballast layer at 90 days after track commission.

\begin{tabular}{lrrrrrrr}
\hline Section & 1 & \multicolumn{1}{c}{2} & \multicolumn{1}{c}{3} & \multicolumn{1}{c}{4} & 5 & $\mathrm{~A}$ & $\mathrm{~B}$ \\
\hline$S_{v}(\mathrm{~mm})$ & 16.3 & 21.2 & 20.6 & 14.8 & 16.0 & 23.8 & 8.8 \\
$\varepsilon_{v}(\%)$ & 5.4 & 7.1 & 6.9 & 4.9 & 5.3 & 7.9 & 2.9 \\
\hline
\end{tabular}

the laboratory (Brown et al., 2007) and is mainly attributed to the interlocking between ballast particles and grids, thus creating larger track confinement.

When the results for sections with similar geogrids are compared, it is observed that the effectiveness of reinforcement of a geogrid to reduce track settlement becomes higher for softer subgrades. Such an observation is in agreement with the results of full-scale tests presented by Ashmawy and Bourdeau (1995). It is also observed that among the four synthetic types used TerraGrid performed most effectively. Although the tensile strength of TerraGrid is equal or lower than those of the others, its aperture size $(40 \mathrm{~mm})$ would enable better interlocking between the ballast particles and grids. This finding agrees well with the criteria for optimum aperture sizes for reinforcing geogrids proposed by Indraratna et al. (2011).

When Sections A and B are compared, the results indicate that the vertical settlements are larger when the subgrade stiffness becomes smaller. This finding contradicts the general perception that ballast subjected to higher stresses would undergo larger vertical strains due to larger degrees of particle breakage (Lackenby et al., 2007). Such contraction is due to that the ballast layer at Section B was contained within the barriers of Mudies Creek bridge and this resulted in essentially no lateral spreading of ballast at this location. At Section A however, the ballast was allowed to expand more freely in the horizontal direction, and larger vertical settlements were thus observed. This observation suggests that the ability of ballast layer to expand horizontally also influences the magnitude of track settlement in addition to the degree of ballast breakage.

\subsection{Transient Deformations of Ballast Layer}

Transient deformations of the ballast layer were measured by the deformation frame. It was observed that the passage of trains with an axial load of 30 tons travelling at $40 \mathrm{~km} / \mathrm{hr}$ resulted in vertical deformations of the ballast layer in the range of 1.5 to $3.0 \mathrm{~mm}$ resulting in average vertical strains between 0.5 and $1.0 \%$. The transient horizontal deformations of ballast were all expansive and in the range -0.5 to $-0.3 \mathrm{~mm}$. This resulted in average horizontal strains of -0.05 to $-0.02 \%$. The horizontal strains were larger near the crest and smaller near the toe of ballast. The average transient strains in both directions of track parts with reinforcement were about $15 \%$ smaller than those without reinforcement regardless of type of geosynthetics employed.

\subsection{Strains Mobilized in Synthetic Grids}

Accumulated longitudinal $\left(\varepsilon_{\ell}\right)$ and transverse $\left(\varepsilon_{t}\right)$ strains at 90 days after track commission measured from the strain gauges below the edges of sleepers are reported in Table 3. The transverse strains were generally larger than longitudinal strains. This is attributed to the relative ease for lateral spreading of the track substructure caused by smaller track restraints in the transverse direction. It was also observed that the values of $\varepsilon_{\ell}$ and $\varepsilon_{t}$ 
Table 3. Accumulated strains in geosynthetics at 90 days after track commission.

\begin{tabular}{lccccc}
\hline Section & 1 & 2 & 3 & 4 & 5 \\
\hline$\varepsilon_{\ell}(\%)$ & 0.80 & 0.78 & 0.92 & 0.61 & 0.60 \\
$\varepsilon_{t}(\%)$ & 0.85 & 1.50 & 0.85 & 0.80 & 1.80 \\
\hline
\end{tabular}

are mainly influenced by the deformations of subgrade. As shown in Table 3, the strains of CombiGrid (Section 5) were relatively large although its higher stiffness could have resulted in smaller strains. This is because the thick general fill at this location underwent large lateral deformations shortly after track commission, resulting in the excessive transverse strains in the geocomposite.

Induced transient strains in the synthetic grids in both longitudinal $\left(\Delta \varepsilon_{t \ell}\right)$ and transverse $\left(\Delta \varepsilon_{t t}\right)$ directions due to the passage of trains with an axial load of 30 tons and a speed of $40 \mathrm{~km} / \mathrm{hr}$ were in the magnitude of $0.14-0.17 \%$. Unlike the case of accumulated strains, smaller values of $\left(\Delta \varepsilon_{t \ell}\right)$ and $\left(\Delta \varepsilon_{t t}\right)$ were observed in grids with higher values of stiffness.

\section{CONCLUSIONS}

A comprehensive field monitoring program was undertaken on instrumented track sections to study the effectiveness of various geosynthetics at improving the overall stability of ballasted rail tracks. Layers of geosynthetics were installed at the ballast-subballast interface and the experimental tracks sections were located on subgrades with different values of stiffness. It was found that geogrids could decrease vertical strains of the ballast with obvious benefits of improved track stability and decreased maintenance cost. The effectiveness of reinforcement increased with decreasing subgrade stiffness. Transient strains of the ballast layer also decreased when geosynthetics were used. The findings of this field study allow for better assessment of the performance of geosynthetic reinforcement to mitigate track degradation caused by cyclic and impact wheel loads. Better understanding of such performance would allow for safer and more effective design and analysis of ballasted rail tracks with geosynthetic reinforcement.

\section{ACKNOWLEDGEMENT}

This study was funded by CRC for Rail Innovation, ARTC and RailCorp through grant R3.117. The financial support is gratefully acknowledged.

\section{REFERENCES}

1. Ashmawy, A. K. and Bourdeau, P. L. (1995). "Geosynthetic-reinforced soils under repeated loading: a review and comparative design study." Geosynthetics International, 2(4), 643-678.

2. Brown, S. F., Kwan, J. and Thom, N. H. (2007). "Identifying the key parameters that influence geogrid reinforcement of railway ballast." Geotextiles and Geomembranes, 25(6), 326-335.

3. Indraratna, B., Nimbalkar, S., Christie, D., Rujikiatkamjorn, C. and Vinod, J. S. (2010) "Field assessment of the performance of a ballasted rail track with and without geosynthetics." Journal of Geotechnical and Geoenvironmental Engineering, ASCE, 136(7), 907-917.

4. Indraratna, B., Hussaini, S. K. and Vinod J. S. (2011). "On the shear behaviour of ballastgeosynthetic interfaces." Geotechnical Testing Journal, ASTM (accepted, in press). 
5. Lackenby, J., Indraratna, B. and McDowel, G. (2007). "The role of confining pressure on cyclic triaxial behaviour of ballast." Géotechnique, 57(6), 527-536.

6. McDowell, G. R. and Harireche, O. (2002). "Discrete element modelling of soil particle fracture." Géotechnique, 52(2), 131-135.

7. RCA Australia (2008). "Geotechnical Investigation Report for Minimbah Bank Third Track." RCA Australia, Newcastle, Australia.

8. Rowe, P. K. and Jones, C. P. (2000). "Geosynthetics: innovative materials and rational design." In: Proceedings, GEOENG 2000, Melbourne, Australia, 1124-1156.

9. Shin, E. C., Kim, D. H. and Das, B. M. (2002). "Geogrid-reinforced railroad bed settlement due to cyclic load." Geotechnical and Geological Engineering, 20(3), 261-271. 
